\title{
Assessment of Stone Columns as a Mitigation Technique of Liquefaction-Induced Effects during Italian Earthquakes (May 2012)
}

\author{
Davide Forcellini' ${ }^{1}$ and Angelo Marcello Tarantino ${ }^{2}$ \\ ${ }^{1}$ Department of Civil Engineering, University of San Marino, 44 Via Salita alla Rocca, 47890 San Marino, San Marino \\ ${ }^{2}$ Civil and Mechanical Engineering Department (DIMeC), University of Modena e Reggio Emilia, 905 Via Vignolese, \\ 41100 Modena, Italy
}

Correspondence should be addressed to Davide Forcellini; davforc@omniway.sm

Received 12 August 2013; Accepted 7 November 2013; Published 27 January 2014

Academic Editors: F. Darve and G. Liu

Copyright (c) 2014 D. Forcellini and A. M. Tarantino. This is an open access article distributed under the Creative Commons Attribution License, which permits unrestricted use, distribution, and reproduction in any medium, provided the original work is properly cited.

\begin{abstract}
Soil liquefaction has been observed worldwide during recent major earthquakes with induced effects responsible for much of the damage, disruption of function, and considerable replacement expenses for structures. The phenomenon has not been documented in recent time with such damage in Italian context before the recent Emilia-Romagna Earthquake (May 2012). The main lateral spreading and vertical deformations affected the stability of many buildings and impacted social life inducing valuable lessons on liquefaction risk assessment and remediation. This paper aims first of all to reproduce soil response to liquefaction-induced lateral effects and thus to evaluate stone column mitigation technique effectiveness by gradually increasing the extension of remediation, in order to achieve a satisfactory lower level of permanent deformations. The study is based on the use of a FE computational interface able to analyse the earthquake-induced three-dimensional pore pressure generation adopting one of the most credited nonlinear theories in order to assess realistically the displacements connected to lateral spreading.
\end{abstract}

\section{Introduction}

Liquefaction-induced deformations are one of the most dangerous collapse situations that can affect structures causing significant consequences such as damage, disruption of function, and considerable replacement expenses. When strong ground shaking occurs, this type of adverse response is commonplace as documented during the earthquakes of Niigata, Japan 1964 [1-4], Dagupan City, Philippines 1990, [57], Chi-Chi, Taiwan 1999 [8], Kocaeli, Turkey 1999 [9], and recent Tohoku earthquake, Japan 2011 [10-15].

During the recent Italian Emilia-Romagna Earthquakes (May 20 and May 29), liquefaction main effects were consequences of the first of these shocks $(M=5.9)$. The most significant phenomena of liquefaction have been observed in San Carlo settlement (located about $17 \mathrm{~km}$ from the epicentre), under the municipality of Sant'Agostino, near Ferrara. The main lateral and vertical deformations induced local and global instability to the buildings and roads closure. Many other typical postearthquake effects were observed such as uniform or differential settlements, sand boils, lateral spreading, soil raptures, water out coming, and many secondary effects. For more details, see Crespellani et al. [16].

Liquefaction mitigation measures generally consist of ground improvement, including removal and recompaction of low-density soils, removal of excess ground water, in situ ground densification, grouting, or surcharging, as described in California Geological Survey [17, Appendix F]. The choice of mitigation technique depends on the site conditions. In particular, the aim of this paper is to assess stone columns as a mitigation procedure to liquefaction-induced effects applied to Italian earthquakes. 


\section{Site Conditions and Remediation}

The areas under investigation are classified on the national scale geological map as Holocene alluvial and fluviallacustrine soil deposits (http://www.pcn.minambiente.it/vie wer/). The Southern part of the Ferrara Province is crossed by Reno River, the second most important river of the EmiliaRomagna Region after Po River. Reno River is an ancient river whose course varied over the plain throughout the centuries. Its waters often stagnated in a wide valley area between Bologna and Ferrara. Some interesting notes on the history of the Reno River can be found in Barbieri [18].

Although the biggest effects of soil liquefaction occur typically during strong earthquakes $(\mathrm{Mw}>7.0)$ at susceptible sites close to the epicenter (e.g., M7.3 Charleston, USA 1886; M9.2 Alaska, USA 1964; M7.6 Niigata, Japan 1964; M7.6 Izmit, Turkey 1999), there have been cases where moderately strong earthquakes (e.g., M6.8 Kobe, Japan 1995; M6.3 Christchurch, New Zealand 2011) have produced widespread liquefaction. The May 20, 2012, M5.9 shock in Emilia Romagna, Italy, is one example of moderate earthquakes yielding extensive liquefaction-related phenomena.

The database of historical liquefaction in Italy Galli [19] demonstrates the existence of a relatively large number of weak to moderate earthquakes (MS > 4.2) producing liquefaction. The Italian territory is characterized by seismicity along the Apennine chain and Eastern Alps. Broad liquefaction-areas exist along the Adriatic, Tyrrhenian coasts, and the Po River alluvial plain. Field measurements were made to estimate the extension of the observed liquefaction phenomenon that was estimated in the first $15-20 \mathrm{~m}$.

The superficial layer consists of paleobanks of alternation of sand (types S1 and S0). Below this strata (whose base is at about $13 \mathrm{~m}$ depth) a silt and clay layer (type A) with abundant organic fraction is located. The base of this layer corresponds to the Holocene and Pleistocene surface. The phreatic water table on June 8 and 18 was registered at around 6 to $8 \mathrm{~m}$ depth.

In this paper, a $28 \mathrm{~m}$ geological model (Figure 1) has been built in order to be representative of several verticals taken in significant locations. The water level was prudentially considered at $0.00 \mathrm{~m}$ depth below surface. Table 1 represents geotechnical parameters, such as density $(\gamma)$, angle of internal friction $(\varphi)$, shear wave velocity $\left(V_{s}\right)$, and permeability $(k)$ for the several layers.

If compared to all the existing techniques, stone columns can be considered the less invasive and the most effective technique, because they combine beneficial effects of densification, reinforcement, and increased drainage (Priebe [20], Mitchell et al. [21], Japanese Geotechnical Society (JGS) [22], Thevanayagam et al. [23], Shenthan et al. [24]). In particular, gravel drains are a rather recent development compared with the more traditional soil densification approaches International Navigation Association (INA) [25]. Gravel drains technique was initially studied by Seed and Booker [26], and then, it has attracted the attention of many researchers such as Ishihara and Yamazaki [27]; Tokimatsu and Yoshimi [28]; Baez and Martin [29]; Boulanger et al. [30]; Brennan and Madabhushi [31]; and Elgamal et al. [32] as well as many practicing consultants as Nippon Kokan,

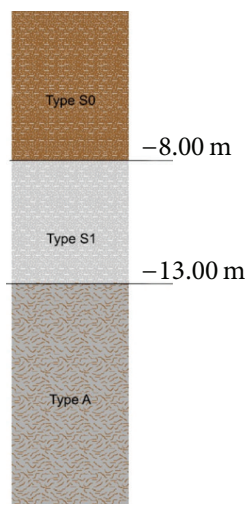

FIGURE 1: Vertical strata with superficial sand layers (type S0 and type S1) and silt and clay layer (type A).

TABLE 1: Ground parameters for each layer.

\begin{tabular}{lccc}
\hline & S0 & S1 & A \\
\hline Mass density $\left(\mathrm{kN} / \mathrm{m}^{3}\right)$ & 19.0 & 20.0 & 19.0 \\
Internal angle of friction $\left(^{\circ}\right)$ & 33.0 & 33.0 & - \\
Shear wave velocity $(\mathrm{m} / \mathrm{s})$ & 200 & 200 & 400 \\
Permability $(\mathrm{m} / \mathrm{s})$ & $10^{-7}$ & $10^{-3}$ & - \\
\hline
\end{tabular}

Japan, and construction companies such as Konoike Construction in Japan and Hayward Baker in the United States (http://www.haywardbaker.com/). In 1985, the gravel drain technique received the Technical Development Award of the Civil Engineering Society of Japan (Saito et al. [33, 34]).

\section{Computational Modeling}

Current methodologies verify the risk for the soil to be subjected to liquefaction without a direct control on excess pore pressure. They only refer to few descriptive parameters based on historic knowledge or taken from geological and geotechnical recognitions and on behaviour analysis results of laboratory cycling test under controlled condition. These empirical methods are used only in preliminary studies allowing general considerations on liquefaction effects and deformation in qualitative terms (for more details, see Forcellini et al. [35]).

The aim of this paper is to realistically assess the entity of the displacements connected to lateral spreading assessing stone column remediation effectiveness. In this regard, study adopts credited nonlinear theories in order to take into account appropriate loading-unloading flow rules as to reproduce the observed strong dilation tendency and resulting increase in cyclic shear stiffness and strength (the "Cyclic Mobility" mechanism). For more details, see Yang and Elgamal [36], Yang et al. [37], and Elgamal et al. [38].

Even if based on these theories, the models have the main advantage to be built up with the most common-used geotechnical parameter. The other parameters are connected with the liquefaction mechanism and they can be obtained by assigned values calibrated on a big variety of realistic cases. In this regard, two different models for cohesionless 
TABLE 2: Characteristics adopted in the study for S0 and S1 strata.

\begin{tabular}{lcc}
\hline & S0 $(0-8 \mathrm{~m})$ & $\mathrm{S} 1(8-13 \mathrm{~m})$ \\
\hline Mass density $\left(\mathrm{kN} / \mathrm{m}^{3}\right)$ & 19.0 & 20.0 \\
$G_{r}$ low-strain shear modulus $(\mathrm{MPa})$ & 70 & 76 \\
at $80 \mathrm{kPa}$ mean effective confinement & & \\
$B_{r}$ low-strain bulk modulus $(\mathrm{MPa})$ & 180 & 200 \\
at $80 \mathrm{kPa}$ mean effective confinement & & \\
Angle of internal friction $\left(^{\circ}\right)$ & 33.0 & 33.0 \\
Phase transformation angle $\left(^{\circ}\right)$ & 26.5 & 27.0 \\
Contraction parameter $c_{1}$ & 0.3 & 0.3 \\
Dilation parameter $d_{1}$ & 0.4 & 0.4 \\
Dilation parameter $d_{2}$ & 2 & 2 \\
Liquefaction parameter $l_{1}$ & 10 & 10 \\
Liquefaction parameter $l_{2}$ & 0.01 & 0.01 \\
Liquefaction parameter $l_{3}$ & 3 & 3 \\
\hline
\end{tabular}

TABLE 3: Characteristics adopted in the study for A stratum.

\begin{tabular}{lc}
\hline & A $(13-28 \mathrm{~m})$ \\
\hline $\begin{array}{l}\text { Mass density }\left(\mathrm{kN} / \mathrm{m}^{3}\right) \\
G_{r} \text { low-strain shear modulus }(\mathrm{MPa})\end{array}$ & 19.0 \\
$\begin{array}{l}\text { at } 80 \mathrm{kPa} \text { mean effective confinement } \\
B_{r} \text { low-strain bulk modulus }(\mathrm{MPa})\end{array}$ & 304 \\
$\begin{array}{l}\text { at } 80 \mathrm{kPa} \text { mean effective confinement } \\
\text { Apparent cohesion at zero } \\
\text { effective confinement }(\mathrm{kPa})\end{array}$ & 1400 \\
\hline
\end{tabular}

and for cohesive soils were considered. The first model for cohesionless materials is developed within the framework of multi-yield-surface plasticity (Prevost [39]), focusing on controlling the magnitude of cycle-by-cycle permanent shear strain accumulation (Parra [40]; Yang [41]; Yang et al. [37]) by specifying an appropriate non-associative flow rule (Prevost [39]; Dafalias [42]; Bousshine et al. [43]; Nemat-Nasser and Zhang [44]; Radi et al. [45]). In particular, the deviatoric component of the flow rule is associative, while nonassociativity is restricted to the volumetric component only, as described in detail in Elgamal et al. [38]. Clay material is modelled as a nonlinear hysteretic material with a Von Mises multisurface Iwan [7] and Mróz [15] kinematic plasticity model, focusing on reproduction of the soil hysteretic elastoplastic shear response (including permanent deformation). The adopted parameters (Tables 2 and 3 ) were calibrated through an identification analysis taking into account nonlinear liquefactioninduced behaviors as specified in OpenSees PL manual Lu et al. [48]. More details on the calibration analysis are shown in Elgamal et al. [32], Forcellini and Tarantino [49], and Forcellini et al. [35].

The presented simulations were conducted using the open-source computational interface OPENSEES PL implemented in OpenSees Yang and Elgamal [36], Yang et al. [37], Yang [41], Mazzoni et al. [50]. It consists of a analysis framework for saturated soil response as a two-phase material following the $u-p$ (where $u$ is displacement of the soil skeleton and $p$ is pore pressure) formulation of Chan [51] and Zienkiewicz et al. [52]. The soil domain is represented by 20-8 node, effective stress fully coupled (solid-fluid) brick elements Lu et al. [48] built up with 20 nodes describing the solid translational degrees of freedom and the eight-corner nodes for the fluid pressure $\mathrm{Lu}$ et al. [48]. In particular, OpenSees PL used in this study, originally calibrated for pile analyses, was modified in order to take into account stone columns behaviour (see also Elgamal et al. [32]). The interface simplifies the 3D spatial soil domain, boundary conditions, and input seismic excitation definition with convenient postprocessing and graphical visualization of the analysis results including the deformed ground response time histories (see $\mathrm{Lu}$ [53]). The ability to simulate the real wave propagation adopting realistic boundaries is of particular importance and significance in order to realistically reproduce the above scenarios.

Recordings were taken from Mirandola (MRN) station, the closest station (about $13.4 \mathrm{~km}$ from the epicentre of May 20, 2012, shock). Figure 2 shows the acceleration time histories of the North-South (NS), East-West (EW), and the vertical (UD) components, respectively, for each component recorded at MRN station. Two 3D models were considered. The first consists of a 3D $20 \times 20 \mathrm{~m}, 28 \mathrm{~m}$ high model (Figure 3), representing the free field conditions and modeled with periodic boundary conditions on account of symmetry (at any spatial location displacement degrees of freedom of the left and right boundary nodes were tied together both longitudinally and vertically using the penalty method). Thus, the base and lateral boundaries were modeled to be impervious, as to represent a small section of a presumably infinite (or at least very large) soil domain by allowing the energy imparted by the seismic event to be removed from the site itself. For more details, see Law and Lam [54], Elgamal et al. [32], Forcellini and Tarantino [49], and Forcellini et al. [35]. The paper adopts a 308 elements mesh, assessed as the most representative compromise from a numerical time consuming calibration where several meshes (up to 3028 elements) were analysed and compared.

The second model consists of a half mesh (Figure 4) simulating a representative cell within a large remediated ground zone. In particular, periodic boundaries offer an effective approach for conducting 3D analyses adopting the symmetry as to investigate a representative remediated "cell," as shown in Law and Lam [54] and Elgamal et al. [32]. The paper adopts a 624 elements mesh, assessed as the most representative compromise from a numerical time consuming calibration where several meshes (up to 7080 elements) were analysed and compared.

\section{Free Field Response}

In this section free field results are shown in terms of excess pore pressure, longitudinal displacements time histories, and entire mesh deformation. In particular, Figure 5 shows that excess pore pressure reached around $120 \mathrm{kPa}$ as the pick values at the base of $\mathrm{S} 1$ stratum $(13 \mathrm{~m})$ but started to rapidly decrease after about $15 \mathrm{~s}$ at the same level as $8 \mathrm{~m}$ and then is fully dissipated at $40 \mathrm{~s}$. The results show that the pick value 

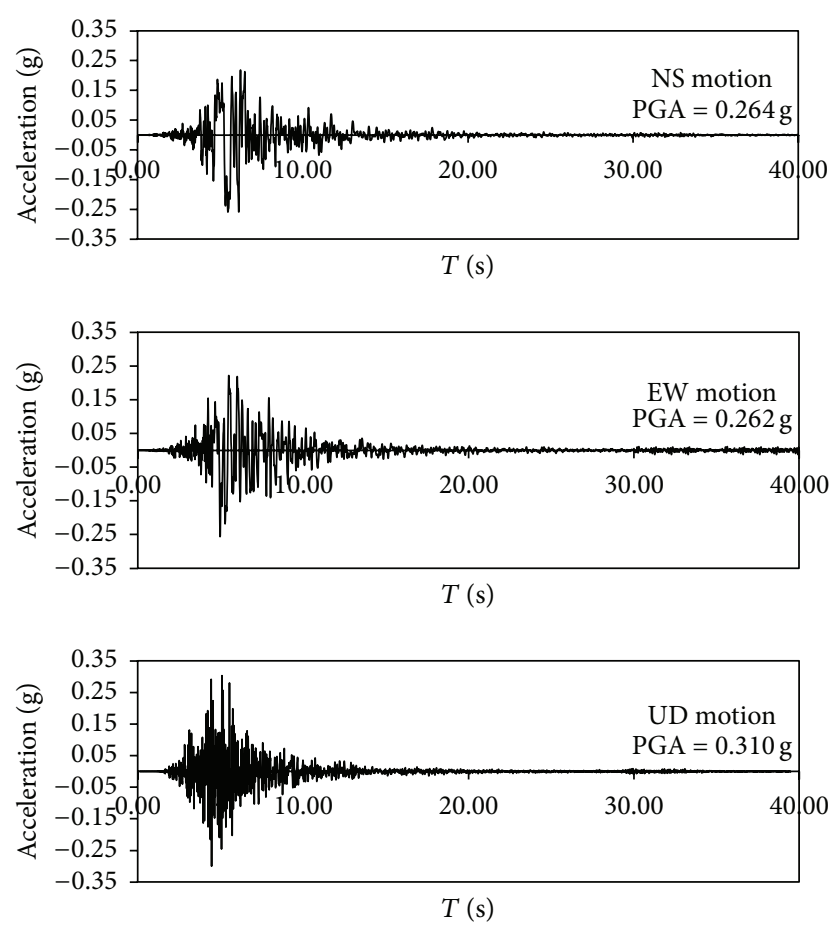

FIgURE 2: Recordings at Mirandola Station (MRN): NS, EW, and UD components [http://www.ingv.it/].

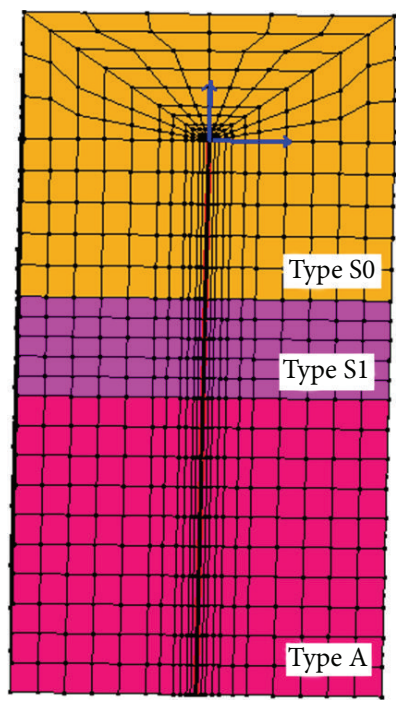

FIgURE 3: Free-field 3D model.

of pore pressure concentrates between $8.00 \mathrm{~m}$ and $13.00 \mathrm{~m}$, meaning that $\mathrm{S} 1$ sand lent stratum results to be the principal cause of liquefaction-induced effects.

This result is confirmed taking into consideration lateral displacements (Figure 6). At $8.00 \mathrm{~m}$ and $0.00 \mathrm{~m}$ depth displacements, no big difference in maximum values (around $32-35 \mathrm{~cm}$ ) can be seen, while at $13.00 \mathrm{~m}$ depth, the final value is around $6 \mathrm{~cm}$. This enforces the role of sand S1 layer in liquefaction-induced lateral spreading generation, since the

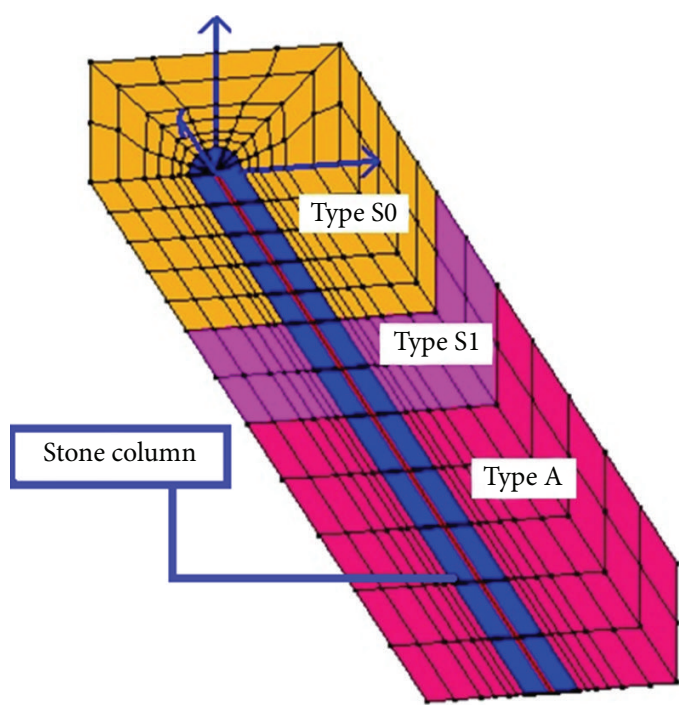

FIgURE 4: The 3D mitigation model.

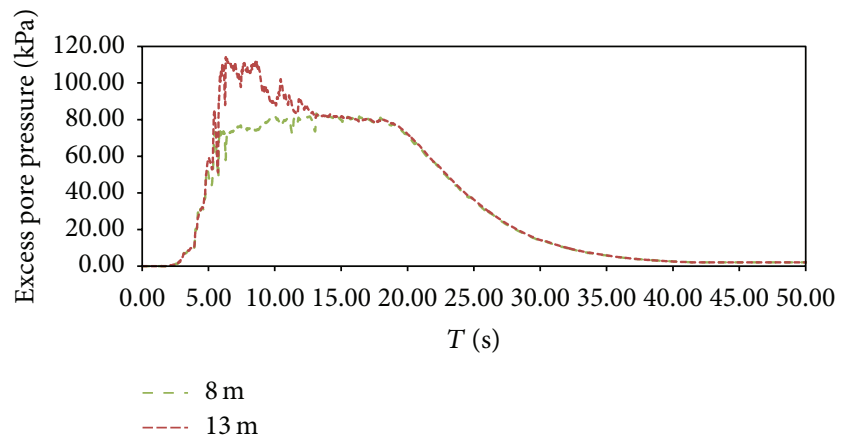

Figure 5: Excess pore pressure at $13.00 \mathrm{~m}$ and $8.00 \mathrm{~m}$ depth.

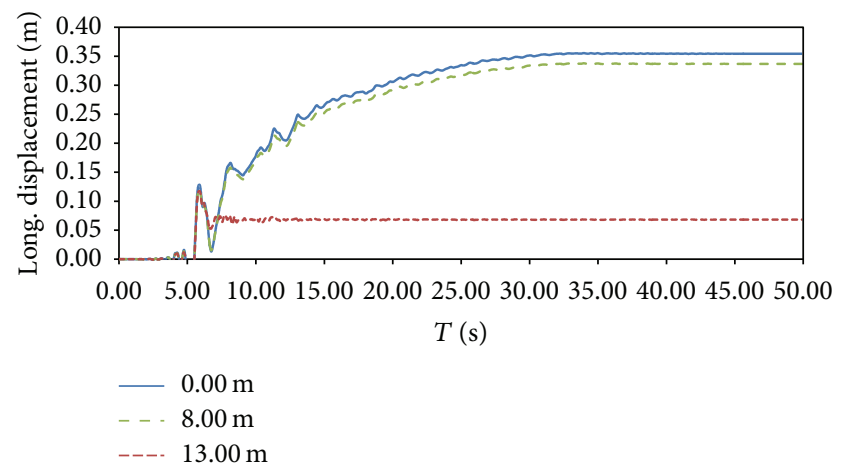

FIGURE 6: Longitudinal displacement at $13.00 \mathrm{~m}, 8.00 \mathrm{~m}$, and $0.00 \mathrm{~m}$ depth.

lateral spreading is totally due to the layers between $8.00 \mathrm{~m}$ and $13.00 \mathrm{~m}$. The entire mesh deformation (Figure 7) at the end of the motions registers such behaviour.

Another important consideration is the values of the modeled permanent displacement at the surface (around $35 \mathrm{~cm}$ ), that is comparable to those measured during the 


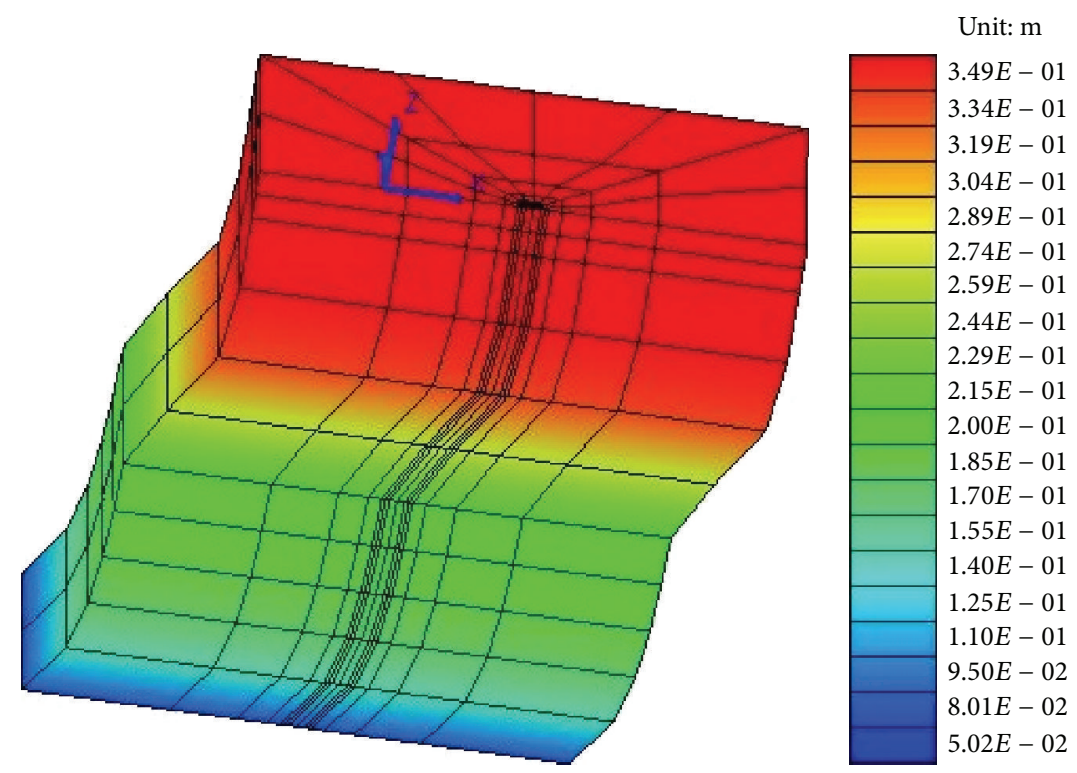

FIgURE 7: Deformed mesh at the end of the motion, scale 1:10.

TABLE 4: Characteristics adopted in the study for SC.

\begin{tabular}{lc}
\hline & SC \\
\hline Mass density $\left(\mathrm{kN} / \mathrm{m}^{3}\right)$ & 19.0 \\
$G_{r}$ low-strain shear modulus $(\mathrm{MPa})$ & 135 \\
at $80 \mathrm{kPa}$ mean effective confinement & \\
$B_{r}$ low-strain bulk modulus $(\mathrm{MPa})$ & 400 \\
at $80 \mathrm{kPa}$ mean effective confinement & 34.0 \\
Angle of internal friction $\left(^{\circ}\right)$ & 26.0 \\
Phase transformation angle $\left(^{\circ}\right)$ & 0.1 \\
Contraction parameter $c_{1}$ & 0.8 \\
Dilation parameter $d_{1}$ & 5 \\
Dilation parameter $d_{2}$ & 0.01 \\
Permeability $k(\mathrm{~m} / \mathrm{s})$ & \\
\hline
\end{tabular}

reconnaissance in San Carlo free field conditions as shown in Crespellani et al. [16].

\section{Assessment of Stone Columns Technique}

In this section stone column (SC) effectiveness in reducing the extent of liquefaction-induced lateral deformation is assessed taking into account several remediation cases. SC was represented by dense sand with gravel permeability of $k=0.01 \mathrm{~m} / \mathrm{s}$ (for more details, see Table 4). In particular, the study assesses the remediation technique taking into account the area replacement ratio $A_{\mathrm{rr}}$, conventionally defined [32] as SC area $\left(A_{r}\right)$ to the tributary area $A$ :

$$
A_{\mathrm{rr}}=\frac{A_{r}}{A}=\frac{\pi \cdot d^{2}}{S^{2}}
$$

where $d$ is stone column diameter and $S$ is spacing between stone columns centers.
TABLE 5: Stone columns models.

\begin{tabular}{lccc}
\hline Name & $D(\mathrm{~m})$ & $A_{\mathrm{rr}}(\%)$ & Displ (cm) \\
\hline FF & - & - & 35.40 \\
$A_{\mathrm{rr}}=0.005$ & 0.10 & 0.05 & 35.30 \\
$A_{\mathrm{rr}}=0.16$ & 0.60 & 1.60 & 22.80 \\
$A_{\mathrm{rr}}=0.37$ & 1.00 & 3.70 & 16.10 \\
$A_{\mathrm{rr}}=0.10$ & 2.00 & 10.00 & 9.30 \\
$A_{\mathrm{rr}}=0.20$ & 3.70 & 20.00 & 6.00 \\
\hline
\end{tabular}

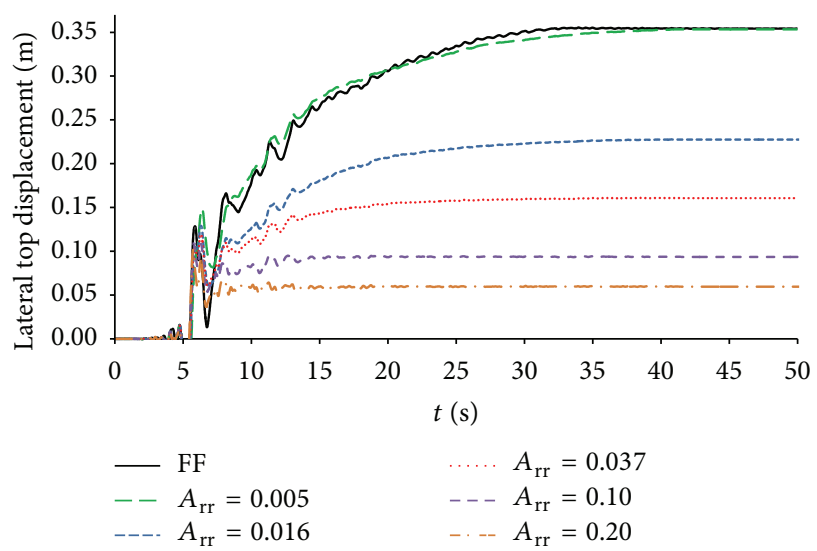

Figure 8: Lateral displacement at surface $(0.00 \mathrm{~m})$ time histories.

In order to take into account stone columns effectiveness, a parametric study varying $A_{\text {rr }}$ from $0.5 \%$ to $20 \%$ as shown in Table 5 was performed.

Figure 8 compares longitudinal displacements time histories at surface $(0.00 \mathrm{~m})$. In particular, it can be seen that free field value $(35.4 \mathrm{~cm})$ is very close with that of $A_{\mathrm{rr}}=0.005$ $(35.0 \mathrm{~cm})$, verifying the effectiveness of mitigation model 


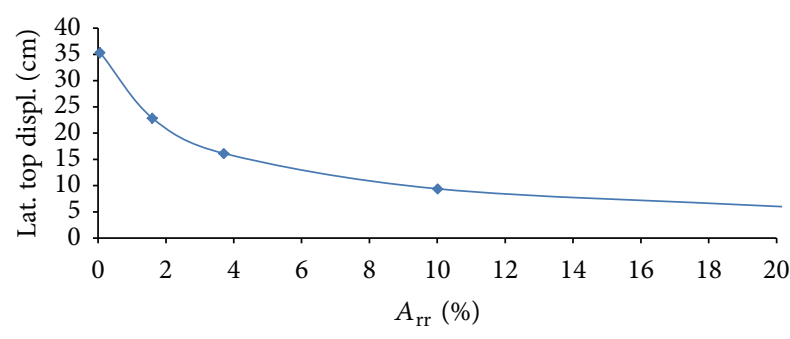

FIGURE 9: $A_{\text {rr }}$-longitudinal top displacement assessment.

with free field mesh: the more the replacement ratio increases, the more the lateral top displacement is reduced.

Figure 9 can be used to assess the best stone columns replacement ratio value (and consequently its remediation cost) compared with the required goal and performance to be obtained (such as minimizing lateral displacement). For example, with $A_{\text {rr }}=0.20$, the lateral top displacement is around $6.0 \mathrm{~cm}$ that can be considered a suitable value for safety conditions.

Figure 10 shows excess pore-pressure time histories at the SC center compared with the far corner of the employed soil mesh (furthest location away from the SC) for $A_{\mathrm{rr}}=0.10$ and $A_{\text {rr }}=0.20$ models. This helps to assess SC important role in reducing the extent of excess pore-pressure buildup. In particular, while in free field model the excess pore pressure reaches the highest level (around $120 \mathrm{kPa}$ ) after $10.00 \mathrm{sec}$ and then it dissipates (Figure 5), in SC models, there is no significant pore-pressure generation within the SC zone. Therefore, the associated drastic reduction in pore pressure is shown to be an important factor in keeping deformations to a potentially tolerable level.

\section{Conclusions}

The paper presents computational modelling, free field response, and stone columns remediation assessment. A parametric study was conducted to assess the effectiveness of SC mitigation technique by gradually increasing the extension of remediation, in order to achieve a satisfactory lower level of permanent deformation. The analyses are aimed to numerically reproduce Italian Emilia-Romagna Earthquakes (May 2012) allowing several considerations.

First of all, free field response underlines the vulnerability of such submerged 3D system in terms of pore-pressure generations and lateral spreading values. Recordings from Mirandola (MRN) station induces typical postearthquake lateral spreading that is confirmed in this study. In particular, results verify the role of sand S1 layer in liquefaction-induced lateral spreading generation.

On the second hand, stone column remediation was found to be effective in reducing the sand stratum lateral deformation taking into consideration area replacement ratio $\left(A_{\text {rr }}\right)$ parameter. In particular, the response helps to assess the most suitable stone columns replacement ratio value (and consequently its remediation cost) compared with the required goal to minimize lateral displacements. Therefore,
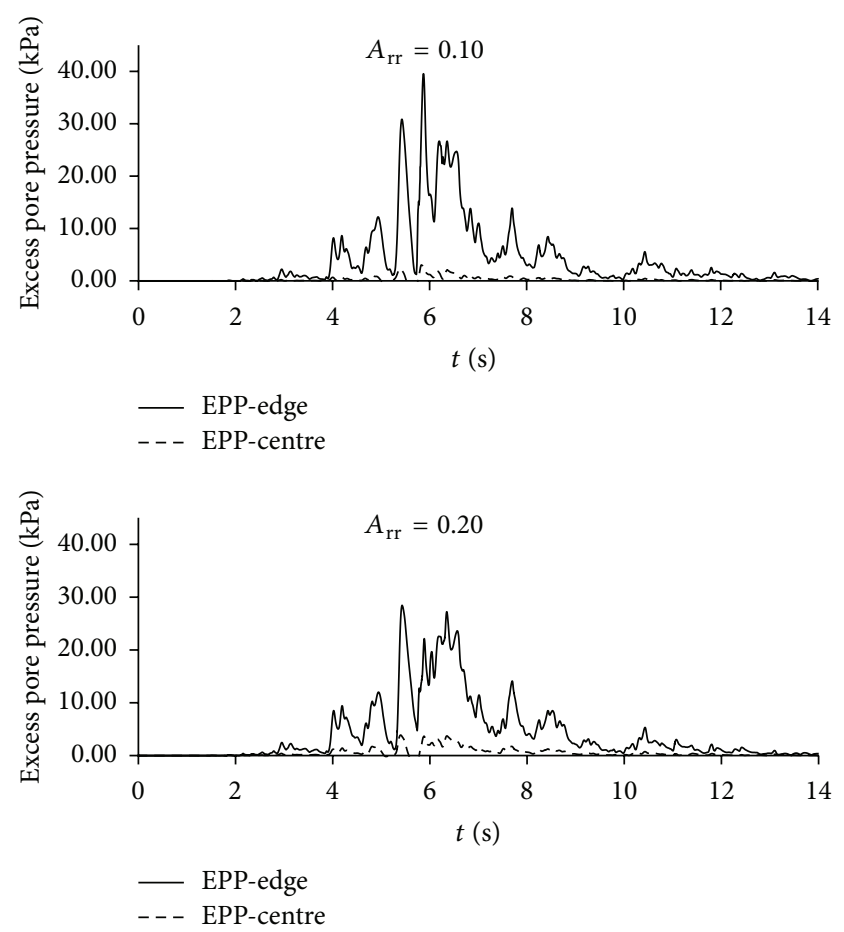

FIGURE 10: Excess pore-pressure time histories at the center and at the edge for $A_{\mathrm{rr}}=0.10$ and $A_{\mathrm{rr}}=0.20$.

mitigation effectiveness and dimensioning design depend on the required performance to be provided in terms of safety level.

In this regard, this study can quantify soil performance to liquefaction-induced effects using metrics that are of immediate use for both preearthquake and postearthquake risk assessment analyses. This kind of response can become very powerful if applied to structures in soil-structure interaction studies. This will be object of further work.

\section{Conflict of Interests}

The authors declare that there is no conflict of interests regarding the publication of this paper.

\section{Acknowledgments}

The authors would like to acknowledge the Italian Foreign Minister (office no. 7) scholarship for non-Italian students that supported and made the study possible. The study was possible thanks to Professor Matteo Berti and Dr. Silvia Franceschini from Dipartimento di Scienze Biologiche, Geologiche e Ambientali, Università di Bologna, and Professor Alessandro Corsini from Dipartimento di Scienze Chimiche e Geologiche, Università di Modena, who assisted the authors in soil properties, the calibration procedure, and model definition. Special thanks are due to Professor Teresa Crespellani, from Dipartimento di Ingegneria Civile e Ambientale, Università di Firenze, Firenze, Italy, for her precious suggestions on the final review of this work. 


\section{References}

[1] H. Kishida, "Damage to reinforced concrete buildings in Niigata city with special reference to foundation engineering," Soils and Foundations, vol. 6, no. 1, pp. 71-88, 1966.

[2] Y. Ohsaki, "Niigata earthquake, 1964 building damage and soil condition," Soils and Foundations, vol. 6, no. 2, pp. 14-37, 1966.

[3] H. B. Seed and I. M. Idriss, "Analysis of soil liquefaction: Niigata earthquake," Journal of the Soil Mechanics and Foundations Division, vol. 93, no. 3, pp. 83-108, 1967.

[4] Y. Yoshimi and K. Tokimatsu, "Settlement of buildings on saturated sand during earthquakes," Soils and Foundations, vol. 17, no. 1, pp. 23-38, 1977.

[5] T. Adachi, S. Iwai, M. Yasui, and Y. Sato, "Settlement of inclination of reinforced concrete buildings in Dagupan city due to liquefaction during 1990 Philippine earthquake," in Proceedings of the 10th World Conference on Earthquake Engineering, pp. 147-152, Balkema, Rotterdam, The Netherlands, 1992.

[6] K. Tokimatsu, S. Midorikawa, S. Tamura, S. Kuwayama, and A. Abe, "Preliminary report on the geotechnical aspects of the Philippine earthquake of July 16, 1990," in Proceedings of the 2nd International Conference on Recent Advances in Geotechnical Earthquake Engineering and Soil Dynamics, pp. 357-364, University of Missouri-Rolla, St. Louis, Mo, USA, 1991.

[7] K. Tokimatsu, H. Kojimaa, S. Kuwayama, A. Abe, and S. Midorikawa, "Liquefaction-induced damage to buildings in 1990 Luzon earthquake," Journal of Geotechnical Engineering, vol. 120, no. 2, pp. 290-307, 1994.

[8] Earthquake Engineering Research Institute (EERI), "Chi-chi, Taiwan, earthquake of September 21, 1999, reconnaissance report," Earthquake Spectra, 2001.

[9] Earthquake Engineering Research Institute (EERI), "Kocaeli. Turkey, Earthquake of august 17, 1999 reconnaissance report," Earthquake Spectra, 2000.

[10] National Research Institute for earth Science and Disaster Prevention (NIED) and Disaster Prevention (NIED), Off the Pacific Coast of Tohoku Earthquake, Strong Ground Motion, National Research Institute for earth Science and Disaster Prevention (NIED), Tsukuba, Japan, 2011.

[11] I. Towhata, H. Goto, M. Kazama et al., "NEWS on gigantic tohoku pacific earthquake in Japan," ISSMGE Bulletin, 2011.

[12] J. Meneses and P. Arduino, Preliminary Observations of the Effects of Ground Failure and Tsunami on the Major Ports of Ibaraki Prefecture, Geotechnical Extreme Events Reconnaissance (GEER), 2011.

[13] S. Bhattacharya, M. Hyodo, K. Goda, T. Tazoh, and C. A. Taylor, "Liquefaction of soil in the Tokyo Bay area from the 2011 Tohoku (Japan) earthquake," Soil Dynamics and Earthquake Engineering, vol. 31, no. 11, pp. 1618-1628, 2011.

[14] S. A. Ashford, R. W. Boulanger, J. L. Donahue, and J. P. Stewart, "Geotechnical quick report on the Kanto Plain Region during the March 11, 2011, Off Pacific Coast of Tohoku Earthquake, Japan," GEER Association Report No GEER-025a, Geotechnical Extreme Events Reconnaissance (GEER), 2011.

[15] K. Tokimatsu and K. Katsumata, "Liquefaction-induced damage to buildings in Urayasu city during the 2011 Tohoku Pacific earthquake," in Proceedings of the International Symposium on Engineering Lessons Learned from the 2011 Great East Japan Earthquake, Tokyo, Japan, 2012.

[16] T. Crespellani, J. Facciorusso, A. Ghinelli, C. Madiai, S. Renzi, and G. Vannucchi, "Rapporto preliminare sui diffusi fenomeni di liquefazione verificatisi durante il terremoto in pianura padana emiliana del Maggio 2012," Sezione Geotecnica Report, Università degli Studi di Firenze, 2012.

[17] California Geological Survey (CGS), Guidelines for evaluating and mitigating seismic hazards in California, California Geological Survey, 2008.

[18] M. Barbieri, "Brevi note storico-geografiche sul Reno," Reno, Campi e Uomini, Rivista Periodica della Pianura, vol. I, no. 1, pp. 10-15, 2003.

[19] P. Galli, "New empirical relationships between magnitude and distance for liquefaction," Tectonophysics, vol. 324, no. 3, pp. 169-187, 2000.

[20] H. J. Priebe, "The prevention of liquefaction by vibro replacement," in Proceedings of the 2nd International Conference on Earthquake Resistant Construction and Design, S. A. Savidis, Ed., pp. 211-219, A. A. Balkema, Rotterdam, The Netherlands, 1991.

[21] J. K. Mitchell, C. D. P. Baxter, and T. C. Munson, "Performance of improved ground during earthquakes," Geotechnical Special Publications, vol. 49, pp. 1-36, 1995.

[22] Japanese Geotechnical Society (JGS), "Special issue on geotechnical aspects of the January 17, 1995 Hyogoken-Nanbu earthquake," Soils Found, 1998.

[23] S. Thevanayagam, G. R. Martin, T. Shenthan, and J. Liang, "Post-liquefaction pore pressure dissipation and densification in silty soils," in Proceedings of the 4th International Conference on Recent Advances in Geotechnical Earthquake Engineering and Soil Dynamics, S. Prakash, Ed., Paper No. 4.28, San Diego, Calif, USA, 2001.

[24] T. Shenthan, R. Nashed, S. Thevanayagam, and G. R. Martin, "Liquefaction mitigation in silty soils using composite stone columns and dynamic compaction," Earthquake Engineering and Engineering Vibration, vol. 3, no. 1, pp. 39-50, 2004.

[25] International Navigation Association (INA), Seismic Design Guidelines for Port Structures, Working Group no. 34 of the Maritime Navigation Commission, Balkema, Rotterdam, The Netherlands, 2001.

[26] H. B. Seed and J. R. Booker, "Stabilization of potentially liquefiable sand deposits using gravel drains," Journal of the Geotechnical Engineering Division, vol. 103, no. 7, pp. 757-768, 1977.

[27] K. Ishihara and F. Yamazaki, "Cyclic simple shear tests on saturated sand in multi-directional loading," Soils and Foundations, vol. 20, no. 1, pp. 45-59, 1980.

[28] K. Tokimatsu and Y. Yoshimi, "Effects of vertical drains on the bearing capacity of saturated sand during earthquakes," Proceedings of the International Conference on Soil Engineering for Protection from Natural Disasters, Asian Institute of Technology, pp. 643-655, 1980.

[29] J. I. Baez and G. R. Martin, "Permeability and shear wave velocity of vibro-replacement stone columns," Geotechnical Special Publications, vol. 49, pp. 66-81, 1995.

[30] R. Boulanger, I. Idriss, D. Stewart, Y. Hashash, and B. Schmidt, "Drainage capacity of stonecolumns or gravel drains for mitigating liquefaction," ASCE Geotechnical Special Publication, vol. 75, no. 1, pp. 678-690, 1998.

[31] A. J. Brennan and S. P. G. Madabhushi, "Effectiveness of vertical drains in mitigation of liquefaction," Soil Dynamics and Earthquake Engineering, vol. 22, no. 9-12, pp. 1059-1065, 2002.

[32] A. Elgamal, J. Lu, and D. Forcellini, "Mitigation of liquefactioninduced lateral deformation in a sloping stratum: threedimensional numerical simulation," Journal of Geotechnical and 
Geoenvironmental Engineering, vol. 135, no. 11, pp. 1672-1682, 2009.

[33] A. Saito, K. Taghawa, T. Tamura, H. Oishi, H. Nagayama, and H. Shimaoka, "A countermeasure for sand liquefaction: gravel drain method," Tech. Rep. 51, Nippon Kokan K.K., Tokyo, Japan, 1987.

[34] A. Saito, K. Ito, and H. Oishi, "Development of gravel drain systems as a remedial measure for soil liquefaction," in Proceedings of the Japanese Society of Civil Engineering, pp. 41-46, 1991.

[35] D. Forcellini, F. della Bartola, and A. M. Tarantino, "Liquefaction-induced lateral deformations computational assessment during Tohoku Earthquake," ISRN Civil Engineering, vol. 2013, Article ID 408961, 8 pages, 2013.

[36] Z. Yang and A. Elgamal, "Influence of permeability on Liquefaction-induced shear deformation," Journal of Engineering Mechanics, vol. 128, no. 7, pp. 720-729, 2002.

[37] Z. Yang, A. Elgamal, and E. Parra, "Computational model for cyclic mobility and associated shear deformation," Journal of Geotechnical and Geoenvironmental Engineering, vol. 129, no. 12, pp. 1119-1127, 2003.

[38] A. Elgamal, Z. Yang, E. Parra, and A. Ragheb, "Modeling of cyclic mobility in saturated cohesionless soils," International Journal of Plasticity, vol. 19, no. 6, pp. 883-905, 2003.

[39] J. H. Prevost, "A simple plasticity theory for frictional cohesionless soils," International Journal of Soil Dynamics and Earthquake Engineering, vol. 4, no. 1, pp. 9-17, 1985.

[40] E. Parra, Numerical modeling of liquefaction and lateral ground deformation including cyclic mobility and dilation response in soil systems [Ph.D. thesis], Rensselaer Polytechnic Institute, Troy, NY, USA, 1996.

[41] Z. Yang, Numerical modeling of earthquake site response including dilation and liquefaction [Ph.D. thesis], Columbia University, New York, NY, USA, 2000.

[42] Y. F. Dafalias, "Bounding surface plasticity I: mathematical formulation and hypoplasticity," Journal of Engineering Mechanics, vol. 112, no. 9, pp. 966-987, 1986.

[43] L. Bousshine, A. Chaaba, and G. de Saxcé, "Softening in stressstrain curve for Drucker-Prager non-associated plasticity," International Journal of Plasticity, vol. 17, no. 1, pp. 21-46, 2001.

[44] S. Nemat-Nasser and J. Zhang, "Constitutive relations for cohesionless frictional granular materials," International Journal of Plasticity, vol. 18, no. 4, pp. 531-547, 2002.

[45] E. Radi, D. Bigoni, and B. Loret, "Steady crack growth in elasticplastic fluid-saturated porous media," International Journal of Plasticity, vol. 18, no. 3, pp. 345-358, 2002.

[46] W. D. Iwan, "On a class of models for the yielding behavior of continuous and composite systems," Journal of Applied Mechanics, vol. 34, pp. 612-617, 1967.

[47] Z. Mróz, "On the description of anisotropic workhardening," Journal of the Mechanics and Physics of Solids, vol. 15, no. 3, pp. 163-175, 1967.

[48] J. Lu, A. Elgamal, and Z. Yang, OpenSeesPL: 3D Lateral Pile-Ground Interaction User Manual (Beta 1.0), University of California, San Diego, Department of Structural Engineering, 2011, http://cyclic.ucsd.edu/openseespl/OpenSeesPL_ UserManual.pdf.

[49] D. Forcellini and A. M. Tarantino, "Countermeasures assessment of liquefaction-induced lateral deformation in a slope ground system," Journal of Engineering, vol. 2013, Article ID 183068, 9 pages, 2013.
[50] S. Mazzoni, F. McKenna, M. H. Scott, and G. L. Fenves, OpenSystem for Earthquake Engineering Simulation User Manual, University of California, Berkeley, California, Calif, USA, 2006, http://opensees.berkeley.edu.

[51] A. H. C. Chan, A unified finite element solution to static and dynamic problems in geomechanics [Ph.D. thesis], University College of Swansea, Swansea, UK, 1988.

[52] O. C. Zienkiewicz, A. H. C. Chan, M. Pastor, D. K. Paul, and T. Shiomi, "Static and dynamic behaviour of soils: a rational approach to quantitative solutions. I. Fully saturated problems," Proceedings of the Royal Society of London A, vol. 429, no. 1877, pp. 285-309, 1990.

[53] J. Lu, Parallel finite element modeling of earthquake site response and liquefaction [Ph.D. thesis], University of California, San Diego, Calif, USA, 2006.

[54] H. K. Law and I. P. Lam, "Application of periodic boundary for large pile group," Journal of Geotechnical and Geoenvironmental Engineering, vol. 127, no. 10, pp. 889-892, 2001. 

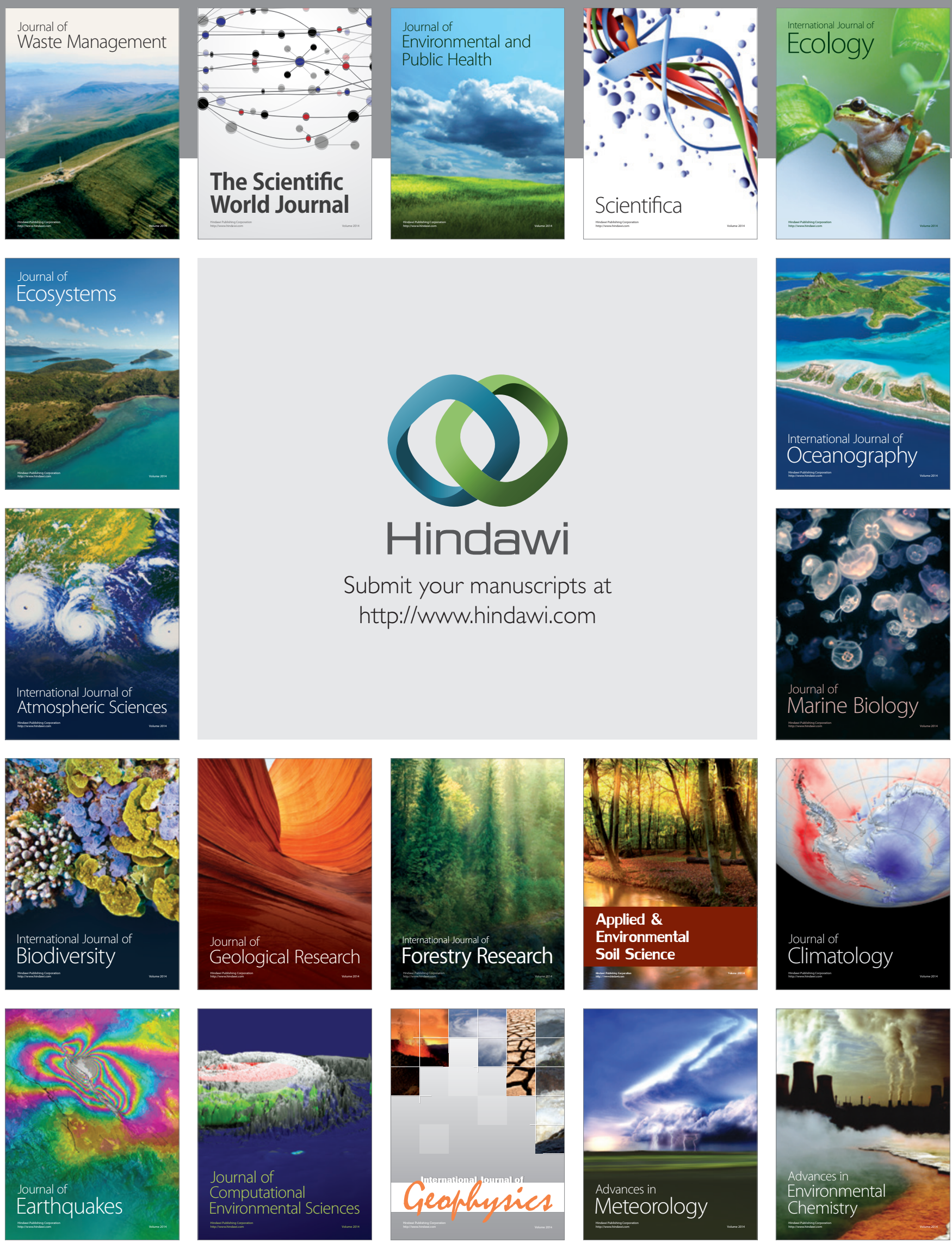